\title{
Degrowth through Income and Wealth Caps?
}

\author{
Buch-Hansen, Hubert; Koch, Max
}

Document Version

Accepted author manuscript

Published in:

Ecological Economics

DOI:

10.1016/j.ecolecon.2019.03.001

Publication date:

2019

License

CC BY-NC-ND

Citation for published version (APA):

Buch-Hansen, H., \& Koch, M. (2019). Degrowth through Income and Wealth Caps? Ecological Economics, 160, 264-271. https://doi.org/10.1016/j.ecolecon.2019.03.001

Link to publication in CBS Research Portal

\section{General rights}

Copyright and moral rights for the publications made accessible in the public portal are retained by the authors and/or other copyright owners and it is a condition of accessing publications that users recognise and abide by the legal requirements associated with these rights.

Take down policy

If you believe that this document breaches copyright please contact us (research.lib@cbs.dk) providing details, and we will remove access to the work immediately and investigate your claim. 


\section{Degrowth through Income and Wealth Caps? \\ Hubert Buch-Hansen and Max Koch}

Journal article (Accepted manuscript*)

\section{Please cite this article as:}

Buch-Hansen, H., \& Koch, M. (2019). Degrowth through Income and Wealth Caps? Ecological Economics, 160, 264-271. https://doi.org/10.1016/j.ecolecon.2019.03.001

DOl: 10.1016/j.ecolecon.2019.03.001

* This version of the article has been accepted for publication and undergone full peer review but has not been through the copyediting, typesetting, pagination and proofreading process, which may lead to differences between this version and the publisher's final version AKA Version of Record.

Uploaded to CBS Research Portal: May २०२०

(1) 2019. This manuscript version is made available under the CC-BY-NC-ND 4.0 license http://creativecommons.org/licenses/by-nc-nd/4.0/ 


\section{Degrowth through Income and Wealth Caps?}

\section{Introduction}

Ecological collapse and extreme and growing economic inequality threaten human civilization as we know it. On the one hand, a number of planetary boundaries are being transgressed. As a consequence, the preconditions for human beings and other species to thrive are rapidly being undermined. On the other hand, economic wealth has to an unprecedented level been concentrated on a few hands while a very large number of people do not have the means to satisfy even their basic human needs (Gough 2017; Raworth 2017; Robinson 2014). Comparative studies into the links between economic growth, material resource use and carbon emissions have indicated that there is no evidence for an absolute decoupling of these parameters (Fritz and Koch 2016; O'Neill et al. 2018). Yet such a decoupling would be required for the rich countries to be able to meet the $\mathrm{CO} 2$ emission targets they have given themselves to keep climate change within certain limits.

In this situation, approaches that deprioritize economic growth in policy-making are becoming increasingly popular. Above all, 'degrowth' scholars call for transitions towards socio-economic systems that would function within ecological boundaries through reductions in the matter and energy throughput of production and consumption patterns while being socially equitable. The eco-social policy instruments needed for such transitions - inter alia work sharing, time-banks, job guarantees, complementary currencies and debt auditing - are intensely debated. Frequent reference has also been made to minimum income schemes and maximum limits on wealth and income as policy tools that can potentially be used to tackle issues related to social inequality during a degrowth transition (e.g., Alexander 2015; Buch-Hansen 2014). However, in contrast to the relatively abundant literature dealing with minimum/basic income systems, the idea to introduce caps on wealth and/or income has received little attention 
in growth-critical scholarship. The development of a conceptual/theoretical approach to understand and motivate such caps and an in-depth discussion of concrete policy proposals concerning various regulatory levels has thus yet to be initiated. We consider this fact unfortunate given the potential that caps could have for reaching the Paris climate targets. According to an Oxfam (2015) report, 'the richest $1 \%$ may emit 30 times more than the poorest 50\%, and 175 times more than the poorest 10\%' (2015: 4). Some scholars, Saez and Piketty among others, suggest a system imposing a tax on the wealthiest individuals (the top 1\%) of $80 \%$ (Guardian 2013). Such a system would however to a smaller extent than caps on wealth and income prevent the rich from leading ecologically harmful lifestyles as it would still allow for extraordinary extents in private wealth in absolute terms.

Currently there seems to be limited popular support for caps on wealth and/or income. One reason for this may be that proposals to date are of a rather abstract nature, which makes them difficult to envision, let alone implement. Our motivation with this paper is to stimulate debate about the eco-social potential of caps on wealth and income and discuss their relevance and impact for a degrowth transition. Such debate, we hope, will simultaneously generate interest in the concrete ways in which such policies could be designed and increase their popularity. Most of the approaches we review have been developed outside the framework of ecological economics and are either economic or sociological, focusing exclusively on social inequality without considering environmental limits. Our special interest will be how so-called 'affluence lines' above which income taxation approximating $100 \%$ could kick in are defined in extant scholarship (e.g., Concialdi 2018). The next two sections review the proposals for wealth and/or income caps made in the relevant literature. We first ask how various scholars motivate the implementation of maximum income and wealth proposals. Subsequently, we turn to the concrete proposals. In the third section, we discuss some critical issues concerning the introduction of maximum wealth and income caps in a degrowth context, focusing on the role of the state, the impact on economic growth and the risk of emigration of highskilled employees and capital flight. We end with a conclusion that summarizes the argument and delineates some future research avenues. 


\section{Motivation of proposals to cap wealth and/or income}

In the growth-critical literature, specifically within a context of shrinking economies in terms of biophysical throughput, it is in Herman Daly's work that one finds the most systematic consideration of maximum caps on wealth and income. In his work on the steady-state economy (SSE), Daly advocates - in addition to birth and resource depletion quotas - a "distributist institution" consisting of minimum and maximum limits on income and maximum limits on wealth: 'If you have a limited total, and you also have a minimum income, then that implies a maximum somewhere. The question then becomes: should that maximum be such that a lot of people can receive it, or just a few? So it's a question of distribution' (Daly 2018: 90). Whereas Daly considers these policies as being important to the functioning of a non-growing economy, a maximum income level has also been advocated by scholars who envision it as an addition to our contemporary growth-based economy. Some of these scholars (e.g., Ramsay 2005) in fact suggest that an income ceiling could stimulate economic growth.

Whether they are for or against a growth-based economic system, proponents of ceilings on wealth and income are united in regarding them as redistributive policies that can serve to reduce inequality and promote a more egalitarian society. Daly (1991: 54) points out that 'maximum limits on both wealth and income are necessary, since wealth and income are largely interchangeable and since, beyond some point, the concentration of wealth becomes inconsistent with both a market economy and political democracy'. The notion that large income disparities and wealth possession undermine democracy is a theme that has inter alia been unfolded in the field of philosophy. Here emerging work on 'limitarianism' takes the position that, for at least two reasons, 'it is not morally permissible to have more resources than are needed to fully flourishing in life' (Robeyns 2017: 2). One reason is that wealthy individuals in many cases use economic resources on acquiring political influence and power (often view a view to protect or further increase their wealth), hereby undermining the political equality of citizens and thus democratic ideals (2017: 6-9; see also Raworth 2017: 172-173). Another reason why "being rich" is regarded as morally impermissible by limitarianism is 
that we live in a world in which financial resources could for instance alleviate extreme poverty. Meeting the needs of the poor is argued to have 'a higher moral urgency' than fulfilling desires beyond what is needed for individuals to lead a flourishing life.

In a similar vein, Daly (1991: 53) argues that 'private property and the whole market economy lose their moral basis' if no limits are placed on incomes and wealth. Noting that classical (liberal) political economists John Stuart Mill and John Locke believed that private property ceases to be legitimate beyond a certain point, Daly (1991: 54-55) observes that wealth becomes an instrument of exploitation if it is not curbed. Other advocates of a ceiling on wealth and income question the extent to which huge pay differentials are justified in the first place. For instance, Maureen Ramsay (2005: 203) writes that 'it would be difficult to make a rational or moral case for the hierarchy of differentials that actually exists'. That is, the size of a salary reflects how much a contribution can be sold for on the market, but the salary does not reflect the actual value created by the contribution. Like other advocates of a cap on wages (e.g., Daly 1996: 203; Pizzigati 2004), Ramsay uses the escalation of CEO pay as an example of salaries that do not reflect the value created by their recipients. The size of CEO pay is typically contingent upon the financial performance of the company. Yet as Ramsay (2005: 204-205) rightly points out, this performance will never solely be the product of one individual's contributions. To the contrary, it will to a large extent be the outcome of a multitude of circumstances (such as market fluctuations, the macroeconomic climate and technological developments) and of the contributions of employees as well as past executives. In other words, 'the market can undervalue a person's contribution and fail to provide a living wage. But the market can also overvalue a person's contribution' (Ramsay 2005: 204). For many advocates of caps on wealth and/or income, this perceived inability of markets to rationally valuate jobs justifies and necessitates externally imposed limits (see also Gough 2017: 180).

Whereas several researchers highlight socio-economic reasons for introducing a ceiling on wealth and/or income, fewer scholars frame caps as a policy instrument that could serve to reduce consumption of scarce natural resources. Daly mainly discusses it as 
an instrument that can serve to make legitimate private property and free markets within the context of the SSE, but also points out that '[g]rowing resource scarcity reinforces this necessity of limits' (1991: 55; see also 1996: 202). Various scholars have noted a link between environmental degradation and income inequality. For instance, Raworth (2017: 172) points out that the social capital needed to push for, implement and enforce environmental legislation is eroded by inequality. Like a number of other authors (e.g., Jackson 2009) she also notes that inequality fuels status competition and consumerism; that is, in contemporary societies, social status, happiness and identity are frequently linked to consumption - and the lifestyles of the wealthy set standards that many people are envious of and aspire to emulate. The increased equality brought about by caps on wealth and/or income could dampen this environmentally harmful form of conspicuous consumerism (see also Demaria et al. 2013: 200).

People at the bottom of the income distribution are not only those least responsible for man-made climate change; they also tend to live in countries most vulnerable to its consequences (Oxfam 2015: 5-6). By contrast, the lives of the wealthiest individuals are to some extent insulated from the problems created by climate change. The vast fortunes of these individuals, writes Pizzigati (2018: 61), 'both rest on environmental degradation and blind the wealthy to it'. He adds that the wealthiest individuals perceive of 'environmental activists as a threat to the corporations they run and a personal affront to the lavish lives they live. These mega rich are funding anti-environment candidates, think tanks, and bogus "grassroots" organizations. Some even bankroll climate-change deniers.' (2018: 62). On this view, then, the existence of a class of very wealthy individuals constitutes a major obstacle to solving the environmental crisis; an obstacle that can be dealt with by imposing a maximum cap on incomes.

In sum, each of the works reviewed in the present section outlines a variety of rationales for reducing economic inequality via caps on wealth and/or income (Table 1). These rationales relate to democracy (e.g., that wealth concentration undermines political equality), morality (e.g., the view that it is more right for resources to be used on alleviating poverty than on purchasing luxury items), market shortcomings (e.g., that 
markets cannot accurately value contributions), environment (e.g., that consumption of scarce natural resources needs to be reduced) and post-growth (that a non-growing economy can only work if economic resources are redistributed).

Table 1: Motivations of proposals to reduce inequality via caps on wealth and/or income

\begin{tabular}{|l|l|l|l|l|l|}
\hline & Democracy & Morality & $\begin{array}{l}\text { Market } \\
\text { shortcomings }\end{array}$ & Environment & Post-growth \\
\hline $\begin{array}{l}\text { Daly (1991, } \\
1996)\end{array}$ & $\mathrm{x}$ & $\mathrm{x}$ & $\mathrm{x}$ & $\mathrm{x}$ & $\mathrm{x}$ \\
\hline $\begin{array}{l}\text { Pizzigati } \\
(2018)\end{array}$ & $\mathrm{x}$ & & $\mathrm{x}$ & $\mathrm{x}$ & \\
\hline $\begin{array}{l}\text { Ramsay } \\
(2005)\end{array}$ & & $\mathrm{x}$ & $\mathrm{x}$ & $\mathrm{x}$ & \\
\hline $\begin{array}{l}\text { Robeyns } \\
(2017)\end{array}$ & $\mathrm{x}$ & $\mathrm{x}$ & & & \\
\hline
\end{tabular}

\section{Concrete proposals}

Having considered the reasons why some scholars advocate wealth and/or income caps, we now turn to the ways in which such systems are envisaged in the literature. The most far-reaching proposal is to cap both income and wealth (e.g., Daly 1991; 1996, Cottey 2014). Here income denotes the flow of earnings a person receives from working, investments and land, whereas wealth can be defined as everything owned by a person that either has monetary or exchange value, minus any debts. While not being the same thing, wealth and income are interrelated: some forms of wealth typically create income; and wealth can be built through income flows. An argument for placing a limit on how much wealth an individual is allowed to possess is that it is the most direct way of tackling the current maldistribution of resources. If such caps were introduced they could potentially bring about a quicker redistribution of resources than could caps 
placed solely on income flows. Still, as Daly (1991: 74) points out, maximum limits on wealth and income can also be introduced gradually, beginning 'near the present extremes and slowly close to a more desirable range'. A downside of wealth caps is that they are certain to run into stronger opposition from wealthy individuals than any of the other proposals considered here (to be sure, none of the proposals would be popular in those circles). On a more practical note, they would be complicated to implement. That is, it requires a continuous assessment of the value of assets, which would be a troublesome task, not least in relation to luxury items such as fine art and jewelry (Pizzigati 2018: 80). Finally, while wealth caps are generally thought of as an instrument that will only affect the very wealthy, it is unclear how the level at which caps are set is to be determined and whether they would target all forms of wealth.

Another proposal is to place an absolute cap on income, imposing a $100 \%$ tax on income exceeding a certain amount. At different points in time, policy-makers have advocated such a system. In Britain, for example, the leader of the Labour party, Jeremy Corbyn, has endorsed a cap on earnings. The ceiling would be 'somewhat higher than' the $£ 138,000$ a year that he earns himself (Guardian 2017). In 1942 US President Franklin D. Roosevelt proposed a $100 \%$ tax on all income in excess of 25,000 USD. The proposal never stood much of a chance of being adopted. It was dismissed in Congress where it was widely regarded as an attack on free enterprise, detrimental to the operation of the free market and a declaration of war against the rich (for a more detailed account of Roosevelt's proposal and its fate, see Leff 1991). ${ }^{1}$ Such reactions are symptomatic of how proposals to place absolute caps on income are met. A disadvantage of such caps is that wealthy individuals have an unambiguous incentive to wage a long-term campaign against them. Moreover, compared to wealth caps, a cap on income (also in the versions dealt with below) constitutes a slower way of tackling wealth inequality. Importantly, however, income caps would gradually reduce the wealth of the wealthiest. That is, it is costly to maintain luxury assets (yachts, mansions etc.)

\footnotetext{
${ }^{1}$ In the Netherlands, a cap on pay (not income more generally) has been introduced in the (semi-)public sector, as a result of which new managers are not allowed to earn more than a minister. We are grateful to Gerrit Stegehuis for making us aware of this.
} 
and as such caps imposed on all forms of income - including salaries/wages, rents, dividends and interests - would force the rich 'to spend down their fortunes' if they 'wanted to continue living life to the lavish fullest' (Pizzigati 2018: 78). The advantages of an absolute cap on income is that it constitutes a straightforward system and that it is less complicated to implement than wealth caps because income typically takes a monetary form.

A third type of proposal is to introduce income caps tied to an income floor. Sam Pizzigati $(2004,2018)$ is the contemporary researcher who has developed this proposal in greatest depth. He advocates a "Ten Times Rule" system under which income ten times bigger than the income floor is taxed $100 \%$. Pizzigati argues that one of the benefits of the system is that while wealthy individuals will oppose its introduction, they would - once it is in place - have a certain incentive to operate within the system. That is, they would have an interest in persuading policy-makers to raise the minimum wage so as to raise the maximum ceiling (2004: 481). In this way he expects the system to raise the living standard of those worst off. Pizzigati is far from the only author proposing a cap set relative to minimum earnings at a 10:1 ratio (see e.g., Ramsay 2005; Daly 1996). But both lower and higher caps have been proposed. For instance, Daly (1996: 202-203) has no objections to a 10:1 ratio, but he (somewhat casually) notes that '[i]f a factor of ten is too egalitarian for our individualistic society, one could substitute a factor of twenty'. That there is no agreement in the literature and beyond on where to cap income is understandable: ultimately any ratio is arbitrary (we return to this issue below). Still, for most authors the optimal ratio comes down to a tradeoff between, on one hand, reducing the gap between the rich and poor while, on the other hand, avoiding that incentives to be productive, innovative and entrepreneurial are not fundamentally damaged (e.g., Daly 1996, Ramsay 2005). For instance, Ramsay observes that human beings are motivated not only by material rewards but also for instance by status, recognition and self-esteem and that it is unnecessary 'to make some individuals hundreds of time richer than others in order to retain incentives' (2005: 207) . 
Versions of this proposal that solely target pay (as opposed to income more generally) have entered the political domain. In Switzerland a referendum was held in 2013 to determine whether a cap should be placed on executive pay at a 12:1 ratio to that of the lowest-paid staff. The referendum was initiated by the youth wing of the Social Democrats which argued that no individuals should be allowed to earn more in a month than other individuals earn in a year. The proposal was for instance opposed by the Swiss Association of Employers, inter alia based on the argument that its adoption would prompt companies to leave Switzerland because of a reduced ability to hire staff with the needed qualifications (Copley 2014). In the referendum, 65\% voted against the proposal. Still, as Gough (2017: 180) remarks, '35 percent suggests considerable support for the idea'.

A review of fair pay in the British public sector has been conducted by Will Hutton. In his interim report he concluded that, in the UK public sector, '[t]here is a strong case for a maximum pay multiple, such as 20:1' (Hutton, 2010: 11). In the report previous experiences with maximum pay multiples are reviewed. It is for instance pointed out that in the 1920s, JP Morgan introduced a system that capped executive pay at twenty times that of junior bankers and that other US companies such as Ben and Jerry's ice-cream company and The Whole Foods Company have more recently had similar policies (Hutton 2010: 21). Elsewhere it has been noted that the Spanish Mondragon cooperative has a range of pay differentials, going from 3:1 to 9:1 (Dietz \& O'Neill 2013: $95)$ and that in the world of professional sports there are examples of maximum wages (Rowlingson \& McKay 2011: 213). However, the historical examples of high profile sport stars such as Björn Borg, Franz Beckenbauer or Michael Schumacher, who left their home countries to enjoy lower taxation elsewhere, as well as nation-state based attempts of taxing the rich to comparatively high extents such as in Sweden in the late 1970s, which led to capital flight, point to the necessity of transnational policy coordination (we return of the potential role of the EU below).

A fourth type of proposal involves placing limits on income exceeding an 'affluence line'. The satisfaction of human needs is central to this approach. To the father of the 
concept, Jan Drewnowski, the affluence line represents an absolute threshold 'the level above which consumption need not and should not rise' (1978: 264) because 'the satisfaction of needs above these standards is not reasonable and has no merits for the individual and is unacceptable from the point of view of the society' (1978: 271). Drewnowski (1978: 264) argued that within the area above the poverty line and below the affluence line 'are found the conditions under which people should live'. Accordingly, it would be the central goal of welfare policies to ensure that the population's needs are satisfied within this area (1978: 275). Drewnowski did not explain how the two lines (minimum and maximum standards of need satisfaction) were to be set in practice, though, and subsequently it was pointed out by Marcelo Medeiros (2006: 5) that it gives rise to substantial problems to define an affluence line in absolute terms.

Medeiros suggests instead that affluence should be defined in relation to poverty. His relational perspective takes as its starting point the notion that poverty in a society is morally unacceptable. He understands poverty not 'as a set of unsatisfied needs, but as an insufficiency of means to satisfy these needs' (2006: 5). Eradicating poverty, then, becomes a question of ensuring income levels enabling each citizen to satisfy his or her basic needs. Medeiros proposes a redistribution system where resources (income) is, in a step-by-step procedure, transferred from the richest to the poorest individuals until no citizen lives below the poverty line: 'when the level of resources of the richest individual reaches the level of the second richest individual, both start transferring equal amounts of resources to the poorest, the same occurs to the following individuals as their level of resources are reached' (Medeiros 2006: 6). On this view, then, the affluence line represents the point above which all income will be transferred from the richest to the poorest in society with a view to eliminate poverty (Medeiros 2006: 15).

Along the same lines, Concialdi (2018: 10) writes that 'the affluence line can be thought of as an answer to the following question: If we were to enable all members of the society to participate in it and to meet their basic needs, what should the maximum income be?' While Concialdi accepts the overall approach developed by Medeiros, he is critical of Medeiros' use of the conventional and arbitrary poverty line in his calculation 
of the affluence line. Instead of the poverty line, Concialdi (2018: 11) introduces a "needs satisfaction line" which represents the minimum income needed for an individual to participate in society. Empirically, this line is established based on the so-called "reference budgets" that have first been developed in the UK with the purpose of establishing a minimum income standard (MIS) required for a full participation in society (Bradshaw et al. 2008; see Davis et al. 2018). A highlighted advantage of reference budgets is that they are socially grounded by drawing on inputs from both citizens and experts (Concialdi 2018: 11), whereas a drawback is that the budgets have not yet been developed for many countries. Concialdi (2018) presents some estimates of an affluence line for France, the UK and Ireland.

The approach advocated by Concialdi constitutes a major step forward in terms of providing the parameters on the basis of which a non-arbitrary maximum income level could be set. Its theoretical basis in needs theory makes it amenable to degrowth research (Koch et al. 2017). Yet like the other perspectives and proposals by Medeiros or Drewnowski it leaves aside the issue of ecological boundaries. The question is, however, to what extent it would be desirable to place limits on income based on an affluence line determined solely in relation to the satisfaction of human needs. One can think about this matter in relation to the "Doughnut" perspective developed by Kate Raworth as 'a radically new compass for guiding humanity this century' (Raworth 2017: 44). The Doughnut consists of two boundaries. First, an inner boundary which is the social foundation. Below this foundation 'lie shortfalls in human well-being, faced by those who lack life's essentials such as food, education and housing' (2017: 45). Second, the outer boundary which is the ecological ceiling beyond which 'lies an overshoot of pressure on Earth's life-giving systems, such as through climate change, ocean acidification and chemical pollution' (2017: 45). In between the two boundaries is an ecologically sustainable and socially just space. Against the backdrop of the current situation, where both boundaries are being transgressed, Raworth considers it the goal to bring all of humanity into this space. 
If one relates the topic of the present paper to the Doughnut perspective (as Raworth briefly does, cf. 2017: 177), both its inner and outer boundaries should be taken into consideration when determining affluence lines and the like. A system that uses the affluence line as the basis for redistributive policies that lift people out of poverty clearly makes sense in relation to the inner (social foundation) boundary. But consumption is to a large extent premised on income, meaning that the more "generous" the affluence line is made, the greater the risk would be that the current ecological overshoot continues and is further exacerbated. For the UK, Gough (2017) shows that if all the British population were at the minimum - according to the MIS reference budgets (Bradshaw et al. 2008) - greenhouse gases would decline by around $40 \%$. However, this would still not be enough to reach the climate targets of the Paris Agreement. Hence, if the ecological ceiling is taken into consideration in addition to satisfaction of human needs, it is very possible that maximum limits on income would have to be set at a lower level than is typically suggested in existing scholarship. By implication, the "needs satisfaction line" and the "affluence line" (and the minimum and maximum income limits) would have to be set in closer proximity to one another.

An additional matter that deserves consideration from a degrowth perspective is whether caps on income are sufficient. While it may be possible to bring everyone above the "needs satisfaction line" through transfers of income exceeding the "affluence line", the introduction of wealth caps may be the best way to prevent the wealthiest from leading environmentally unsustainable lifestyles. That is, income caps constitute a slower and less direct means of redistributing wealth than income caps combined with wealth caps. The question is thus whether income caps alone suffice in a situation where a number of planetary boundaries are being transgressed. While many advocates of degrowth will undoubtedly consider the introduction of an affluence line system tied to a "needs satisfaction line" a major step forward, there is thus an argument for either introducing an additional wealth cap system or for attempting to find ways to bring wealth levels into the definition of the affluence line. Overall, the wealth cap instrument has received less attention - and is thus conceptually less developed than income caps. Discussion and further conceptualisation of wealth caps is thus very 
much needed. The main pros and cons of the various proposals reviewed in this section are summarised in Table 2.

Table 2: Advantages and disadvantages of different types of cap systems

\begin{tabular}{|l|l|l|}
\hline & Advantages & Disadvantages \\
\hline Cap on wealth & $\begin{array}{l}\text { - Potentially the quickest and } \\
\text { most direct way to tackle wealth } \\
\text { inequality }\end{array}$ & $\begin{array}{l}\text { - Likely to face stronger political } \\
\text { opposition than the other } \\
\text { proposals. } \\
\text { - Complicated to implement } \\
\text { - Arbitrary cap level }\end{array}$ \\
\hline Absolute income cap & $\begin{array}{l}\text { - Straightforward system } \\
\text { - Easier to implement than } \\
\text { wealth caps }\end{array}$ & $\begin{array}{l}\text { - Slower way to tackle wealth } \\
\text { inequality than wealth caps. } \\
\text { - Certain to face long-term } \\
\text { opposition from wealthy } \\
\text { individuals } \\
\text { - Arbitrary cap level }\end{array}$ \\
\hline $\begin{array}{l}\text { Income cap tied to minimum } \\
\text { income }\end{array}$ & $\begin{array}{l}\text { - Straightforward system } \\
\text { - Wealthy individuals are given } \\
\text { some incentive to operate within } \\
\text { system once it is in place. }\end{array}$ & $\begin{array}{l}\text { - Slower way to tackle wealth } \\
\text { inequality than wealth caps. } \\
\text { - Arbitrary ratio }\end{array}$ \\
\hline $\begin{array}{l}\text { Affluence line tied to needs } \\
\text { satisfaction line }\end{array}$ & $\begin{array}{l}\text { - Takes into consideration } \\
\text { - Income caps are set at non- } \\
\text { arbitrary levels }\end{array}$ & $\begin{array}{l}\text { - Slower way to tackle wealth } \\
\text { inequality than wealth caps. } \\
\text { - The issue of ecological } \\
\text { boundaries is left aside }\end{array}$ \\
\hline
\end{tabular}

\section{Critical issues in a degrowth context}

Caps on wealth and/or income are not in the focus of policy debates in a degrowth context. To change this state of affairs it is useful to confront some of the most critical issues head-on. Specifically, we focus on the role of the state and the provision of economic growth based on the contemporary growth-critical debate. Moreover, we address the potential flight of capital and high-skilled employees based on economic policy debates. We add to these a discussion of how ecological parameters could be 
considered in the definition of an 'affluence line'. There are doubtless other controversial issues in relation to an implementation of wealth and income caps. However, we hope that our preliminary selection will help stimulate further debate.

\section{The role of the state}

As policy instruments that promise to reduce inequality, caps on wealth and/or income are attractive from a degrowth perspective. In practice, however, the implementation of these policies would undoubtedly require the existence of active and 'interventionist' states and international organisations. Raising the issue of how (existing and reformed) states could assist a transformation from a capitalist growth to a sustainable degrowth economy is somewhat against the growth-critical mainstream where neither state theories nor policies are particularly popular. In fact much degrowth thought has tended to view states as part of the problem rather than as the solution (Cosme et al. 2017). Yet Cosme et al. also demonstrate that most concrete policy proposals tabled by growth-critical scholars are rather traditional 'top-down' and state-led than 'bottom up' and community-led. Hence, there is a necessity to both theoretically and practically address the contradiction between conceptualising the state as an external power, incapable of initiating change in an ecological and social direction, and politically appealing to it to do precisely this.

Though further-going state-theoretical debates are outside the scope of this research overview, we would like to mention that Poulantzas' concept of 'condensation' of wider societal struggles within the state, for example, indicates that the political actions of the state are far from independent from what goes on beyond it (Poulantzas 1978). The existing state apparatus could be used to initiate a transition that breaks with the growth imperative that currently frames state strategies. Bourdieu's notion of the 'right and left hand' of the state can be interpreted in similar ways (Bourdieu 2015). In both perspectives, however, bottom-up mobilisation (Buch-Hansen 2018) would be the necessary condition for any efficient eco-social top-down regulation. To be sure, neither do bottom-up mobilisations necessarily take an eco-social direction (the French 'yellow vests' movement is only the most recent illustration of the fact that ecological and social 
goals continue to be pursued in competition rather than in an integrated way) nor do actual current state policies (not only in the United States and Brazil) give much cheer. But a dynamic and relational understanding of the state based on Poulantzas and Bourdieu nevertheless indicates that one does not necessarily have to wait for the 'withering away' of the state before any progress can be made. Since policy tools such as caps on wealth and income address social inequality and the ecological crisis in tandem they have the potential of not only uniting social and ecological movements but also of framing corresponding state strategies. Eco-social policies in general and maximum wealth and income schemes in particular presuppose for the time being a dirigiste and 'active interventionist "innovation state"' (Gough 2017: 197) capable of implementing a range of policies concerning taxation and the ownership of wealth to offset regressive impacts on lower-income groups that are likely to accompany an economic retraction. This more active role of the state would actually not contradict the logic of the current EU 20/20 Strategy, which emphasizes the 'investment' functions of social policies (designed to strengthen people's skills and capacities and support them to participate fully in employment and social life), if social investment were to be complemented by 'environmental investment' and corresponding eco-social policies (Vanhercke et al. 2018).

In this context it can be noted that Pizzigati (2018: 49-50) sees a major role for governments and states in pushing for a system with less extreme pay differentials. He for instance proposes that governments could reward companies that have modest pay differentials between employees and top managers by giving them tax breaks or preferential treatment in contract-bidding processes. Doing so would have the additional benefit - seen from a degrowth perspective - of giving an advantage to cooperatives and social enterprises vis-à-vis large shareholder owned corporations.

\section{Economic growth}

As was observed above, income caps is a policy instrument that has been advocated both by growth-critical scholars and by scholars who see it as an instrument that could serve to stimulate growth. Here it can be noted that various studies have pointed out 
that one of the detrimental consequences of inequality is that long-term economic growth is harmed. For instance, an OECD report from 2015 finds that rising income inequality in the OECD - mainly due to the inability of low income households to invest in education - 'knocked 4.7 percentage points off cumulative growth between 1990 and 2010' (OECD 2015: 26). The report moreover notes that the 'capital income generated by wealth concentration is likely to deepen income inequality still further, with implications for deteriorating economic growth' (2015: 36). Other research suggests that the concentration of wealth strangles aggregate demand in the economy (Pizzigati 2018: 89). There is, after all, a limit to how much of their wealth and income very rich individuals can spend on consumption. If a good portion of their economic resources were distributed to individuals whose human needs are currently not satisfied, aggregate demand and consumption would increase. As Ramsay (2005: 208) argues, a maximum wage linked to a minimum wage could 'stimulate growth by reducing poverty and welfare expenditure, raising living standards and boosting consumer demand for products in general consumption categories.' The unintended consequence of such welfare policies could indeed be that more people than previously are lifted into a situation where they can afford and practice ecologically harmful lifestyles (Koch and Fritz 2014: 698).

However, as already mentioned, a fair distribution of economic resources to enable all human beings to satisfy their needs is a key goal for degrowth advocates. While caps on wealth and income could play an important role in that regard, from a degrowth perspective it is needless to say of paramount importance that these policy instruments do not contribute to boost economic growth. Here it is worth keeping in mind that economic growth is an outcome that has many determinants. It is not the case that simply because a policy that reduces inequality is implemented, the GDP growth rate will surge. Many different policy instruments affect the direction in which an economic system develops and the effect of any one instrument depends on the operation of others. In other words, the type of "policy mix", which caps on wealth and income form part of, is crucial in determining the overall effect they would have. A "degrowth mix" could involve policies such as caps on resource use (Daly 1991; Feasta 2008), the 
introduction of complementary currencies (Hornborg 2017), a reduction in working time (Schor 2015) and policies that are directly aimed at ensuring that income is spent in an environmentally sustainable manner.

\section{Emigration and capital flight}

A standard argument against higher taxation and a maximum income ceiling in particular is that high-skilled employees may leave the country to earn more money elsewhere. Undoubtedly, emigration would increase in response to the introduction of wealth and/or income caps. Yet Spangenberg (2014: 72) suggests that the argument is relevant for 'only a very small group of overpaid top earners, most of them in the banking and speculation sector.' Indeed geographical capital mobility is only an option for those companies and their employees that are not engaged in 'physical production'. Significant parts of the latter companies is 'fixed' (capital) at a given location, since the amortisation of costs for buildings, machinery etc. takes a long period of time (Marx 1992). However, this is not the case in financial industries, which have grown disproportionally relative to physically productive sectors such as manufacturing in the last decades. Hence, finance capital and its employees are geographically mobile to a much greater extent than the productive economy. At the same time, the financial sector is especially prone to producing speculative bubbles. It features comparatively high profit margins and bonuses for its top-employees. It is the latter that are relatively mobile and most likely to seek work elsewhere if a maximum income of some sorts were to be implemented at national scale. In this situation, much speaks for transnational policy coordination and international regulations to complicate the resulting competition of nation states for high-skilled labour power (see the below Conclusion). In the US context, research has found that while migration of millionaires is responsive to the top income tax rates, 'the magnitude of the migration response is small and has little effect on the millionaire tax base' (Young et al. 2016: 423). Moreover, millionaires do not 'cluster on the low-tax side of state borders' (ibid.: 423).

Another standard argument against caps on wealth and/or income is that it would result in capital flight. That is, if some countries took steps to introduce such caps, it is easy to 
foresee that wealth and wealthy individuals would move to jurisdictions with no such caps. ${ }^{2}$ As is the case with productive companies, wealth invested in fixed assets such as real estate cannot easily be moved abroad. Wealthy individuals typically have a substantial chunk of their wealth invested in such assets in the country in which they are based. Pizzigati - who proposes a cap on income but not on wealth - points out that if rich individuals tried to sell all their fixed assets, markets would be overflown and the exchange value of assets such as office buildings, mansions and fancy cars would take a dive (Pizzigati 2004: 496). The prospects of such a scenario could deter some wealthy individuals from fleeing the country in the face of a maximum income cap. Liquid assets, to the contrary, are easy to transfer to another country. Even if it was made illegal to move assets over a certain amount it would be difficult to altogether prevent flight of this form of capital. However, in this case owners of liquid capital would also have to renounce their citizenship and become citizens of a country without maximum caps. This could discourage some capital flight, also because countries with caps may in other respects be more attractive to live in than "cap-free societies". Ramsay (2005) suggests that countries with income caps would overall be more socially cohesive and thus safe. She also reckons, however, that such advantages may not be sufficient to make it attractive for most of the very wealthy individuals to stay, as such individuals are able to lead their lives without feeling the effects of inequality (see also Ramsay 2005: 209). Overall, countries that were to introduce caps on wealth and income would indeed be exposed to - but not defenseless against - capital flight. The extent to which capital flight could be avoided would, again, in no small measure depend on steps taken by states and perhaps international organizations.

\section{Ecological limits}

One way of addressing ecological limits within the debate around caps on wealth and/or income is to apply the 'dual strategy' (Doyal \& Gough 1991) of policy formation which combines the codified knowledge of experts and the experimental knowledge of those whose needs are under consideration. It was developed by needs theorists as a novel

\footnotetext{
${ }^{2}$ Capital flight is already a major problem. Currently the equivalent of $10 \%$ of world GDP is estimated to be held in tax havens (Alstadsæter et al. 2018). See also Pizzigati (2018: chapter 4) for a discussion of this issue.
} 
way for citizens, experts, government and civil society representatives to work together in democratic and deliberative forums, and to identify the goods and services necessary for needs satisfaction within a particular social and cultural context and environmental limits. The essential premise is that all individuals, everywhere in the world, at all times, have certain basic needs. These must be met in order for people to avoid harm, to participate in society and to reflect critically upon the conditions in which they find themselves. Only if needs are understood in universal terms, applied across time and place, can we plan for and measure progress toward our social and environmental goals, both globally and into the future (Gough 2017; for a degrowth context see Koch and Buch-Hansen 2016). However, this does not only apply to minimum need satisfaction levels for which reference budgets are already developed (see above) but, in principle, also for maximum levels beyond which further consumption does not significantly contribute to a person's wellbeing. Similar to existing reference budgets, which are co-developed in democratic forums by expert, citizen representatives and policy makers and then equivalized in monetary minimum incomes, social and ecological limits for maximum consumption could be defined, contextualised for local levels and, finally, translated into monetary amounts for individuals or households as the basis for taxation and/or caps.

This would require much more methodological work than the scope of this review article allows. However, the point of departure for this work would be the distinction between the characteristics of needs and the culturally, socially and temporarily specific means employed to satisfy them. Max-Neef's Human Scale Development (HSD) methodology introduced the term 'satisfier' to highlight the culturally-specific ways in which universal needs are fulfilled in practice. The inherent diversity allows for the identification and comparison of present and alternative modes of satisfiers and has been made to the object of in-depth qualitative research. Guillén-Royo (2015) has compiled contextual, conceptual and empirical aspects of the HSD approach and applied these to sustainability and wellbeing research. Indeed, if exclusively defined by expert knowledge and input, both human needs and their minimum and maximum satisfaction levels may be considered paternalistic and externally imposed. This is why authors such 
as Guillén-Royo and Gough highlight the importance of participatory exercises such as consultations, focus groups and deliberative forums in determining specific actions to achieve high levels of wellbeing within planetary limits and in the exploration of the forms that needs satisfiers take within a community. Even though such forums have no more than advisory character (Buchs and Koch 2019), they bring together laypersons, 'experts' and policy makers in novel ways, which has led to policy change in different national and local contexts (Guillén-Royo 2015).

Themes of future deliberative forums could include size of home, goods and appliances in the home, leisure activities and transport means. This may help to delineate what may be regarded as safe and 'sustainable consumption corridors' including minimum and maximum levels of 'natural and social resources that individuals are entitled to have access to' (Di Giulio \& Fuchs 2014: 187). Hence, such forums could significantly contribute to both research and policy making, if a societal consensus about sustainable needs satisfiers could be established, that is, on what is seen as 'excessive' and 'luxury' in contrast to what may count as 'necessary'. Experts could, for example, contribute to such forums with information on the size of ecological footprints that are within sustainable levels, while the whole forum could deliberate on what kind of lifestyles and production patterns this may allow. It could also identify maximum consumption levels for particular needs and define their monetary equivalents as 'maximum reference budgets'. These could then be used as basis for caps.

\section{Conclusion}

In comparison to the relatively abundant literature dealing with minimum/basic income systems advocates of degrowth have devoted little attention to maximum limits on wealth and/or income. Despite frequent appeals that such policy measures would be a necessary part of a wider ecological and social transition, the degrowth research community has as of yet not produced any advanced conceptual/theoretical approach to understand and motivate such caps. Neither have concrete policy proposals for an implementation of maximum caps on wealth and/or income been provided. As a first step to fill this gap we have reviewed relevant proposals towards understanding and 
operationalizing various cap schemes, the bulk of which have been developed outside the degrowth research community and without much consideration of environmental limits. The most fully developed proposals suggest the definition of maximum incomes as some quantitative proportion from minimum incomes (10:1, 20:1 etc.). Some of the proposals are currently underdeveloped. Most notably, the wealth cap instrument requires further elaboration. For instance, should all forms of wealth be targeted, how should the cap level be set and how could such a cap be implemented in practice?

Most of the approaches reviewed here appear to be hampered by a degree of arbitrariness as regards where to cap income. Yet the same applies to most incomerelated taxes. At what levels these kick in and to what extent primary incomes are taxed, for example, are a reflection of wider societal power relations, particularly between capital and labour. It is far from coincidental that wage and wealth inequalities in the advanced capitalist countries were much lower in the 1960s than now, when trade unions in Fordism - in the context of full employment of the (male) workforce and much smaller geographical capital mobility - were in a much better bargaining position than in today's much more globalized, finance-driven and flexible accumulation mode (Koch 2012; Sayer 2015; Leonardi 2019).

On top of such political economy and power-theoretical reasoning, which let us deprioritize 'correct' formulas to depict exact quantitative proportions from minimum incomes, we would highlight the specificity of local contexts and the significance of democratic deliberation in defining and legitimizing maximum limits for wealth and/or income. On the one hand, despite the fact that this includes a degree of arbitrariness we agree with the necessity of defining an 'affluence line' - the amount of resources above which $100 \%$ taxation would kick in - at a central level. For Europe this would best be done at EU level to complicate capital flight and migration of high-skilled labour. On the other hand, however, we would argue that local affluence lines could oscillate around this centrally defined amount to consider specific contexts. Such an upwards and downwards rescaling of responsibilities within economic, social and environmental policy making would be in line with the general direction of change that characterize the 
EU 'social model' since its origin (Vanhercke et al. 2018). It will undoubtedly require a momentous uphill struggle across Europe to upgrade austerity and the 'Maastricht' criteria with policy measures capable of ensuring limits for wealth and/or income. A however small indication that this bottom-up mobilisation is starting is the recent open letter to turn the EU Stability and Growth Pact into a Stability and Wellbeing Pact, which was published in the Guardian on 16/09/2018 as well as in several other newspapers and languages. At the moment of writing, this letter was signed by about 90,000 EU citizens.

Rather than suggesting here concrete quantitative affluence lines for particular countries we would plead for expanding the methodology developed for the identification of reference budgets to identify and operationalize minimum needs satisfaction levels to also identify maximum satisfaction levels of human needs: In contrast to subjective wellbeing indicators such as happiness, human needs as objective wellbeing indicator are satiable: thirst or hunger are human needs which can be satisfied. Beyond a certain level of satisfaction, however, further consumption of appropriate needs satisfiers such as water or food does not contribute to needs satisfaction but instead to unintended side-effects such as obesity. One of the main future research directions would then be the identification of monetary equivalents to maximum needs satisfaction as maximum reference budgets. We would argue that a $100 \%$ taxation of incomes that exceed this reference budget for maximum needs satisfaction would be legitimate and indeed necessary in an ecologically constrained world. However, to make such a policy shift more acceptable to the electorate, it is important not to dictate it as top-down measure but to develop and deliberate it in democratic forums where experts, citizens and policy makers come together. Reference budgets for maximum needs satisfaction would be an important input to such forums and could constitute the point of departure from where local affluence lines are drawn.

\section{Acknowledgements}

We are grateful to four anonymous reviewers, Tuuli Hirvilammi, Håkan Johansson and the participants at the "Eco-social policies for degrowth transitions" session at the 2018 
VI International Degrowth Conference in Malmö for many very constructive comments. Needless to say, we alone are responsible for any remaining errors.

Max Koch acknowledges that his contribution benefited from funding from the FORMAS (Swedish Research Council FORMAS) project The New Urban Challenge: Models of Sustainable Welfare in Swedish Metropolitan Cities (grant no. 2016-00340).

\section{References}

Alexander, S. (2015). Basic and maximum income. In G. D'Alisa, F. Demaria, \& G. Kallis (Eds.), Degrowth. A vocabulary for a new era (pp. 146-148). London \& New York: Routledge.

Alstadsæter, A. Johannesen, N. Zucman, G. (2018) Who owns the wealth in tax havens? Macro evidence and implications for global inequality, Journal of Public Economics 162, 89-100.

Bourdieu, P. (2015). On the state. Lectures at the Collège de France 1989-1992. Cambridge: Polity Press.

Bradshaw, J., Middleton, S, Davis, A. et al. (2008). A minimum income standard for Britain What people think. London: Joseph Rowntree Foundation.

Buch-Hansen, H. (2014) Capitalist diversity and degrowth trajectories to steady-state economies, Ecological Economics, 106, 173-179.

Buch-Hansen, H. (2018). The prerequisites for a degrowth paradigm shift: Insights from critical political economy. Ecological Economics 146, 157-163.

Buchs, M. and Koch, M. (2019) Challenges for the Degrowth Transition: The Debate about Wellbeing. Futures 155: 155-165.

Concialdi, P. (2018). What does it mean to be rich? Some conceptual and empirical issues. European Journal of Social Security, 20(1), 3-20.

Copley (2013) Swiss voters reject proposal to limit executives' pay, Reuters, November 24. Retrieved from https://www.reuters.com/article/us-swiss-vote-pay/swiss-votersreject-proposal-to-limit-executives-pay-idUSBRE9AN0BW20131124

Cosme, I., Santos, R., and O'Neill, D. (2017). Assessing the degrowth discourse: A review and analysis of academic degrowth policy proposals. Journal of Cleaner Production 149, 321-334.

Cottey, A. (2014). Technologies, culture, work, basic income and maximum income. Al and Society, 29(2), 249-257.

Daly, H. E. (1991). Steady-state economics. Washington: Island Press.

Daly, H. E. (1996). Beyond Growth. Boston: Beacon Press.

Daly, H.E. (2018). Economies of Scale. Interview by Benjamin Kunkel. New Left Review 109: 81-104. 
Davis, A. Hirsch, D., Padley, M. and Shepherd, C. (2018). A Minimum Income Standard for the UK, 2008-2018: continuity and change. London: Joseph Rowntree Foundation.

Demaria, F., Schneider, F., Sekulova, F., \& Martinez-Alier, J. (2013). What is Degrowth? From an Activist Slogan to a Social Movement. Environmental Values, 22(2), 191-215.

Dietz, R., \& O'Neill, D. (2013). Enough is enough. Building a sustainable economy in a world of finite resources. San Francisco: Berrett-Koehler Publishers.

Di Giulio, A. and Fuchs, D. (2014). Sustainable Consumption Corridors: Concept, Objections, and Responses. GAIA 23, 184-192.

Doyal L \& I Gough (1991). A Theory of Human Need. Basingstoke: Macmillan.

Drewnowski, J. (1978). The Affluence Line. Social Indicators Research, 5, 263278.

Feasta (2008). A Fair Way to Cut Greenhouse Emissions. Dublin: Feasta.

Fritz, M. \& M. Koch (2016) Economic Development and Prosperity Patterns Around the World: Structural Challenges for a Global Steady-state Economy. Global Environmental Change 38, 31-48.

Gough, I. (2017). Heat, Greed and Human Need Climate Change, Capitalism and Sustainable Wellbeing. Cheltenham: Edward Elgar.

Gurardian. (2013). Why the $1 \%$ should pay tax at $80 \%$. Retrieved from https://www.theguardian.com/commentisfree/2013/oct/24/1percent-pay-taxrate-80percent)

Guardian. (2017). Jeremy Corbyn calls for maximum wage law. Retrieved from https://www.theguardian.com/politics/2017/jan/10/jeremy-corbyn-calls-formaximum-wage-law

Guillén-Royo M (2015). Sustainability and Wellbeing: Human-scale Development in Practice. London: Routledge.

Hornborg, A. (2017) How to turn an ocean liner: a proposal for voluntary degrowth by redesigning money for sustainability, justice, and resilience. Journal of Political Ecology. 24, 623-632.

Hutton, W. (2010). Hutton Review of Fair Pay in the public sector: interim report. London.

Jackson, T. (2009). Beyond the Growth Economy. Journal of Industrial Ecology, 13(4), 487-490.

Koch, M. (2012) Capitalism and Climate Change. Theoretical Discussion, Historical Development and Policy Responses. Basingstoke: Palgrave Macmillan.

Koch, M. and Buch-Hansen, H. (2016) Human needs, steady-state economics and sustainable welfare, in: Koch, M. and Mont, O., eds. Sustainability and the political economy of welfare. London: Routledge. 
Koch, M., Buch-Hansen, H. and Fritz, M. (2017). Shifting priorities in degrowth research: An argument for the centrality of human needs. Ecological Economics 138, 74-81.

Koch, M. and Fritz, M. (2014) Building the eco-social state: Do welfare regimes matter? Journal of Social Policy 43(4), 679-703.

Leff, M. (1991) The Politics of Sacrifice on the American Home Front in World War II, The Journal of American History 77(4), 1296-1318.

Leonardi, E. (2019) Bringing Class Analysis Back in: Assessing the Transformation of the Value-Nature Nexus to Strengthen the Connection Between Degrowth and Environmental Justice. Ecological Economics 156, 83-90.

Marx, K. (1992) Capital Volume II. London: Penguin.

Medeiros, M. (2006). The Rich and the Poor: The Construction of an Affluence Line from the Poverty Line. Social Indicators Research, 78(1), 1-18.

OECD. (2015). In It Together: Why Less Inequality Benefits All. Paris: OECD Publishing.

O'Neill, D W, Fanning, A L, Lamb, W F and Steinberger, J K. (2018). A Good Life for All within Planetary Boundaries. Nature Sustainability 1(2), 88-95.

Oxfam (2015) Extreme carbon inequality, Oxfam Media Briefing, 2 December. Max-Neef M (1991). Human Scale Development: Conception, Application and

Further Reflections. London: The Apex Press.

Pizzigati, S. (2004). Greed and Good: Understanding and Overcoming the Inequality that Limits Our Lives. The Apex Press.

Pizzigati, S. (2018). The Case for a Maximum Wage, Cambridge: Polity. Poulantzas, N. (1978). State, power and socialism. London: NLB.

Ramsay, M. (2005). A modest proposal: the case for a maximum wage. Contemporary Politics, 11(4), 201-216.

Raworth, K. (2017). Doughnut Economics. London: Random House Business Books.

Robeyns, I. (2017). Having too much. In J. Knight \& M. Schwartzberg (Eds.), NOMOS LVI: Wealth. Yearbook of the American Society for Political and Legal Philosophy. New York University Press.

Robinson, W I. (2014). Global Capitalism and the Crisis of Humanity. Cambridge: Cambridge University Press.

Rowlingson, K., \& McKay, S. D. (2011). Wealth and the wealthy. Exploring and tackling inequalities between rich and poor. Bristol: The Policy Press.

Sayer, A. (2015) Why We can't Afford the Rich. Bristol: Policy Press.

Schor, J. (2015) Work sharing. In G. D'Alisa, F. Demaria, \& G. Kallis (Eds.), Degrowth. A vocabulary for a new era (pp. 195-197). London \& New York: Routledge. 
Spangenberg, J. H. (2014). Institutional change for strong sustainable consumption: sustainable consumption and the degrowth economy. Sustainability: Science, Practice and Policy, 10(1), 62-77.

Vanhercke, B., Ghailani, D., \& Sabato, S. (2018). Social Policy in the European Union: State of Play 2018. Brussels: European Trade Union Institute and European Social Observatory.

Young, C., Varner, C., Lurie, I. Z., Prisinzano, R. (2016) Millionaire Migration and Taxation of the Elite: Evidence from Administrative Data, American Sociological Review, 81(3), 421-446. 